\title{
Esnek İnsülin Tedavisi Alan Tip 1 Diyabetli Çocuk ve Adolesanların 2 Yıllık İzlem Sonuçları ve Tedaviye Uyumun Değerlendirilmesi
}

\author{
Evaluation of 2-Year Follow-up Results and Compliance to \\ Treatment of Children and Adolescents with Type 1 Diabetes \\ Mellitus Receiving Flexible Insulin Therapy
}

Pelin ÇELIK' ${ }^{1}$, Zeynep ŞIKLAR², Merih BERBEROĞLU²

${ }^{1}$ Ankara Şehir Hastanesi, Çocuk Hastanesi, Gelişimsel Pediatri, Ankara, Türkiye

${ }^{2}$ Ankara Üniversitesi Tıp Fakültesi, Çocuk Sağlığı ve Hastalıkları Anabilim Dalı, Çocuk Endokrinoloji Bilim Dalı, Ankara, Türkiye

\section{Öz}

Amaç: Esnek insülin tedavisi, öğünlerin zamanı, yiyecek seçimi ve öğünlerdeki insülin dozunun karbonhidrat sayımı yaparak kişinin yaşam tarzına göre ayarlandığı yoğun insülin tedavisidir. Çalışmamızın amacı tip 1 diyabetli çocuklarda esnek insülin tedavisinin metabolik kontrole, antropometrik özelliklere ve sağlık parametrelerine etkilerinin incelenmesi ve tedaviye uyumun değerlendirilmesidir.

Gereç ve Yöntemler: Esnek insülin tedavisini balayı dönemi sonrası en az 2 yıl süre kullanan tip 1 diyabetli 39 hastanın, dosya verileri retrospektif olarak incelendi. İki ylllik izlemde ortalama HbA1c düzeyi >\%7.5 olan hastalar grup $1, \leq \% 7.5$ olan hastalar grup 2 olarak tanımlandı. Her grubun 2 yıllık seyri değerlendirildi, gruplar karşılaştırıld.

Bulgular: Hastaların ortanca diyabet süresi 52 (25-152) aydı. Grup 1 'de 23 (\%59), grup 2'de 16 (\%41) hasta mevcuttu. Gruplar arasında diyabet süresi benzerdi ( $p>0.05$ ). Grup 2'deki olguların, başlangıç ortanca HbA1c düzeyleri daha yüksekti $(p=0.046)$. Her iki grubun da tedavinin 1. ylında HbA1c düzeyinin azaldığı $(p<0.05)$; tedavinin 2. yllında grup 2'nin iyi kontrollerini sürdürdükleri, ancak grup 1'de HbA1c düzeyinin arttığı saptandı ( $p<0.001)$.

Grup 2'deki hastaların rölatif ağırlıkları (RA) tedavinin 2. ylında başlangıca göre artmakla beraber ( $p=0.031$ ), idealdi. Grup 1 'deki hastaların ise tedavi başlangııına göre 2 yillık izlem sonunda RA'ları değişmedi ( $p>0.05$ ). Her 2 gruptaki olgular da genetiği içinde büyüyen ve yillık uzamaları normal olan olgulardı. Esnek tedavi alan tüm hastalar değerlendirildiğinde izlemin 2. ylında, ortalama insülin dozlarının arttı̆̆ı saptandı ( $p=001)$. Grup 2'de diyetine uyan ( $(p=0.038)$, karbonhidrat sayımı yapan ( $\mathrm{p}=0.025)$ ve daha az hazır yemek tüketen ( $\mathrm{p}=0.018)$ hastaların sıklığı grup 1'den daha fazla saptandı.

Gruplar arasında ciddi hipoglisemi ve diyabetik ketoasidoz sıklğı benzerdi ( $p>0.05)$. Grup 1'deki trigliserid, total kolesterol, LDL, VLDL düzeyleri grup 2'den yüksek, HDL düzeyi ise düşük olmasına rağmen, istatistiksel anlamlı fark saptanmadı ( $p>0.05)$. Dislipidemi gelişen hastaların ortanca diyabet süresi, dislipidemi gelișmeyen hastalardan daha uzundu ( $\mathrm{p}=0.018)$.

Sonuç: Esnek insülin tedavisi, sağlıklı beslenen ve etkili karbonhidrat sayımı yapan çocuklarda, RA'da anormal artış yapmadan $\mathrm{HbA} 1 \mathrm{c}$ düzeyini $\leq \% 7.5$ 'e düşürebilir.

Anahtar Sözcükler: HbA1c, Insülin, Karbonhidrat, Tip 1 diyabet

\section{ABSTRACT}

Objective: Flexible insulin therapy is an intensive insulin therapy where the time of meals, food selection, and administration of insulin dosage according to the patient's lifestyle by carbohydrate counting. We aimed to investigate the effects of flexible insulin treatment on metabolic control, anthropometric properties and health parameters in children with type 1 diabetes and to evaluate compliance with treatment.

\footnotetext{
(1D) Çıkar Çatışması / Conflict of Interest: Tüm yazarlar adına, sorumlu yazar çıkar çatışması olmadığını belirtir.

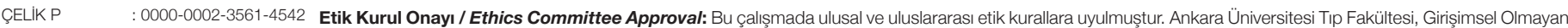

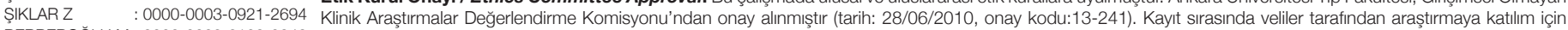
BERBEROĞLU M : 0000-0003-3102-0242 bilgilendirilmiş bir onay imzalanmıştır.

Yazarların katkısı / Contribution of the Authors: ÇELiK P: Araștıma ve/veya makalenin hipotezini veya fikrini olușturan, Hasta takibinde sorumluluk almak, ilgil biyolojik malzemelerin toplanması, veri yönetimi ve raporlama, deneylerin yürütülmesi, SIKLAR Z Sonuçara ulașmak için planlama/metodoloji belirleme, Yazım ve dilbilgisi dıșında bilimsel olarak gönderilmeden önce makaleyi gözden geçirme, BERBEROĞLU M: Araștırma ve/veya makalenin hipotezini veya fikrini oluşturan, dilbilgisi dışında bilimsel olarak gönderilmeden önce makaleyi gözden geçirme, BERBEROGLU M: Araştırma ve/veya makalenin hipotezini veya
Sonuçlara ulaşmak için planlama/metodoloji belirleme, Yazım ve dilbilgisi dışında bilimsel olarak gönderilmeden önce makaleyi gözden geçirme

Atıf yazım șekli / How to cite : Çelik P, Șıklar Z, Berberoğlu M. Esnek İnsülin Tedavisi Alan Tip 1 Diyabetli Çocuk ve Adolesanların 2 Yıllık İlem Sonuçları ve Tedaviye Uyumun Değerlendirilmesi . Türkiye Çocuk Hast Derg 2020;14:339-347.
}

Yazışma Adresi / Correspondence Address:

Pelin ÇELIK

Ankara Șehir Hastanesi, Çocuk Hastanesi, Gelișimsel Pediatri, Ankara, Türkiye

E-posta: drpelincelik06@gmail.com
Geliş tarihi / Received : 06.02.2020 Kabul tarihi / Accepted : 07.04.2020 Elektronik yayın tarihi : 17.06 .2020 Online published

DOI: 10.12956/tchd.683063 
Material and Methods: Medical records of 39 children receiving flexible insulin therapy at least 2 years after honeymoon period were retrospectively evaluated. Patients were grouped according to mean HbA1c as group 1 (>7.5\%) and group 2 ( $\leq 7.5 \%)$. The 2 -year followup of each group was evaluated, groups were compared.

Results: Median diabetes duration was 52 (25-152) months. Group 1 and 2 included 23 (59\%) and 16 (41\%) patients, respectively. Diabetes duration was similar ( $p>0.05)$. Group 2 had higher initial HbA1c levels $(p=0.046)$. HbA1c levels of both groups were decreased at first year $(\mathrm{p}<0.05)$. In the second year, group 2 maintained good glycemic control whereas group 1 had increased HbA1c level $(p<0.001)$. Although mean relative weight $(\mathrm{RW})$ increased in the second year $(\mathrm{p}=0.031)$ in group 2 , their mean RW was ideal. RW did not changed in group 1 after 2 year follow-up ( $>0.05)$. All patients had normal growth according to their genetic potential. Mean insulin dose of patients was increased in second year $(p=0)$. Compliance to diet $(p=0.038)$, carbohydrate count $(p=0.025)$ and less fast food consumption( $p=0.018$ ) were more common in group 2 .

The frequency of severe hypoglycemia and diabetic ketoacidos were similar ( $p>0.05)$. Group 1 had insignificantly higher triglyceride, total cholesterol, LDL, VLDL and lower HDL levels ( $p>0.05)$. Patients with dyslipidemia had longer median diabetes duration than without dyslipidemia $(\mathrm{p}=0.018)$.

Conclusion: Flexible insulin therapy may provide $\leq \% 7.5 \mathrm{HbA} 1 \mathrm{c}$ levels in children who have healthy eating habits and count carbohydrate without causing any abnormal increase in RW.

Key Words: Carbohydrate, Insulin, HbA1c, Type 1 diabetes

\section{GiRiş}

Tip 1 diyabet tedavisindeki temel amaç hipoglisemiye neden olmadan ideal glisemik kontrol ile yeterli ve uygun büyümeyi sağlamaktır. Diyabet Kontrolü ve Komplikasyonları Çalışması'nda (DCCT-Diabetes Control and Complications Trial) yoğun insülin tedavisinin glisemik kontrolü iyileştirdiği ve diyabetik komplikasyonları azalttığı gösterilmiştir (1). Yoğun insülin tedavisi, sürekli bazal insülin salınımı ve öğünlerle ilişkili insülin piklerinden oluşan fizyolojik insülin sekresyonunu taklit etmeyi amaçlayan, hızlı ve uzun etkili insülin preparatlarının çoklu enjeksiyonlar şeklinde uygulanmasıdır (2).

Karbonhidratlar, beslenme sonrası kan şekerini ve insülin intiyacını belirleyen temel gıdalardır. Karbonhidrat sayımı, ana ve ara öğünlerde tüketilen karbonhidrat miktarının hesaplanmasına dayalı bir öğün planlama yöntemidir (3). Esnek insülin tedavisi, tip 1 diyabetli hastaların kan şekeri değerlerini izleyerek, öğün alım zamanına ve karbonhidrat sayımına göre insülin tedavilerini kendilerinin belirleyip uyguladıkları yoğun insülin tedavisidir (4). Tip 1 diyabetli çocuk ve erişkinlerde yapılan çalışmalarda, esnek öğün ve insülin tedavisinin, HbA1c düzeyinde azalma yönünde etkisinin olduğu, hipoglisemi sıklığını arttırmadığı, önemli kilo değişikliğine neden olmadığı ve çocukların normal final boya ulaşabildikleri bildirilmiştir $(5,6)$. Ayrıca esnek insülin tedavisinin, öğünlerin sıklığı, zamanlaması, porsiyon miktarı ve fiziksel aktivitede daha fazla esneklik sağlayarak hastaların yaşam kalitesini arttırdığı gösterilmiştir $(2,7)$.

Çalışmamızın amacı esnek insülin tedavisinin glisemik ve metabolik kontrole, antropometrik özelliklere etkilerinin incelenmesi ve tedaviye uyumun denetlenmesidir.

\section{GEREÇ ve YÖNTEMLER}

Çalışmaya üniversitemizin, Çocuk Endokrinoloji Bilim Dalı'nda izlenen ve esnek insülin tedavisini en az 2 yıl süre kullanan tip
1 diyabetli hastalar dahil edildi. Balayı döneminde $(0.5$ Ü/kg/ gün'den az insülin intiyacı) olan hastalar çalışmaya alınmadı.

Çocuk/ailelere, esnek insülin tedavisi başlangıcında beslenme, öğün planlaması ve karbonhidrat sayımı eğitimi verildi. Hastaların 3 ayda bir çocuk endokrinoloji uzmanı tarafından klinik ve metabolik kontrolleri yapıldı. Her kontrolde boy, kilo, vücut kitle indeksi (VKI), rölatif ağırlık (RA) ve boy standart sapma skorunu (BSDS) içeren antropometrik özellikleri, Tanner skorlamasına göre puberte evreleri, tedavi şemaları ve günlük total insülin dozları (Ü/kg/gün), HbA1c, kan basıncı ölçümleri, enjeksiyon yeri bulguları, hipoglisemi sıklığı ve ketoasidoz varlığı kaydedildi. Antropometrik değerlendirmelerde Olcay Neyzi Türk çocukları standartları esas alındı $(8,9)$. Boy için önce BSDS, sonra hedef boy ve hedef boy standart sapma skoru (HBSDS) hesaplandı. BSDS'den HBSDS çıkarılarak genetiğe uyum hesaplandı. Aradaki fark <1 olduğunda olgu, genetiği ile uyumlu olarak yorumlandı. Ağırlık için önce VKI, sonra RA hesaplandı. RA 90 ile 110 arası normal, 90'ın altı zayıf, 110 -120 arası fazla kilolu, 120'nin üstü ise obez olarak kabul edildi. Her kontrolde hastaların karbonhidrat sayma becerileri, diyet uyumu, hazır yiyecek, gazlı içecek, şekerli meyve suyu tüketimi değerlendirildi. Tanıda ve sonrasında her yıl bakılan çölyak hastalığı ve haşhimoto tiroiditi taraması, lipid profilleri (LDL,HDL,VLDL, Trigliserid) esnek tedavi başlangıcı, tedavinin birinci ve ikinci yılı için retrospektif olarak hasta takip formuna kaydedildi.

HbA1c düzeyi Adams ${ }^{\text {TM }}$ A1c HA-8160 cihazı ve aynı marka kit ile HPLC yöntemi (yüksek performanslı sıvı kromatografisi) ile çalışıldı (Referans aralığı=\%4.5-6). Dosya kayıtlarından bir yıl süresince ölçülen HbA1c değerleri toplanıp, kontrol sayısına bölünerek her yıl için ortalama $\mathrm{HbA} 1 \mathrm{c}$ düzeyleri hesaplandı. Esnek insülin tedavisi ile 2 yıllık izlem süresinde ortalama HbA1c düzeyleri > \%7.5 olan olgular grup 1 (kötü kontrol grubu), ortalama $\mathrm{HbA} 1 \mathrm{c}$ düzeyleri $\leq \% 7.5$ olan olgular ise grup 2 (iyi kontrol grubu) olarak tanımlandı (10). Her grubun 2 yıllık seyri değerlendirildi. Tedavi başlangıcında ve tedavi sonunda gruplar karşılaştıııldı. 
Ciddi hipoglisemi ve diyabetik ketoasidoz (DKA) atak sayısI, 100 hasta ylında atak sayısı olarak değerlendirildi (11). Ciddi hipoglisemi bilinç değişikliğinin (konfüzyon, nöbetler, koma) eşlik ettiği veya glukagon enjeksiyonu veya intravenöz glukoz infüzyonu gerektiren, kan şekerinin $<50 \mathrm{mg} / \mathrm{dl}$ düşmesi olarak tanımlandı. DKA atağı kan pH'sının $<7.3$ ile $\mathrm{HCO}<15$ mEq/l olması ve intravenöz sıvı ve insülin intiyacının olması olarak tanımlandı.

Çalışmanın yapılabilmesi için üniversitemizin Klinik Araştırmalar Etik Kurul Komisyonu'ndan etik kurul onayı (tarih: 28/06/2010, onay kodu:13-241) alındı. Çalışmaya katılan her bireyin yasal vasisine, bilgilendirme yapılarak, aydınlatımış onam formu imzalatıdı.

\section{İstatistiksel değerlendirme}

Çalışmada tüm veriler SPSS 15.0 istatistik programı kullanılarak elde edildi. Gruplar arasında yüzde değer karşılaştıııırken Chisquare testi kullanıldı. Grup sayısı 2 olduğunda ortalama değer karşılaşıııldığında dağlım normalse t testi; dağılım normal değilse Mann- Whitney $U$ testi kullanıldı. Grup içi zaman karşılaştıııımasında dağııım normalse paired t test, dağııım normal değilse Wilcoxon testi, zaman sayısı 2'den fazla olduğunda ise dağılım normalse tekrarlı ölçümlerde varyans analizi, dağılım normal değilse friedman testi kullanıldı. Tanımlayıcı istatistikler; kategorik değişkenler için sayı ve yüzde olarak verildi. Sürekli veriler grup içinde normal dağlım gösteriyorsa ortalama $\pm S D$, göstermiyorsa ortanca (en küçük-en büyük) olarak verildi. Tüm testlerde anlamlılk düzeyi $p<0.05$ olarak alındı.

\section{BULGULAR}

Çalışmaya dahil edilen 39 hastanın 21'i (\%53.8) kız, 18'i (\%46.2) erkekti. Ortanca diyabet tanı yașı 9.19 (3-16.44) yaș ve ortanca diyabet süresi 52 (25-152) aydl. Dokuz (\%23) hasta 24-36 ay, 18 (\%46.2) hasta 37-72 ay, 7 (\%18) hasta 73-108 ay, 5 (\%12.8) hasta ise 108 aydan uzun süre diyabet tanısı ile izlenen hastalardı. On iki (\%30.8) hastada otoimmün tiroidit, 2 (\%5.1) hastada çölyak hastalığı eşlik ediyordu.

Hastaların esnek insülin tedavi başlangııındaki verileri Tablo l'de görülmektedir. Esnek insülin tedavisine başlama yaşı ortalaması $10.5 \pm 3.29$ yıldı. Hastaların 24 (\%61.5)'üne tanıdan itibaren esnek tedavi şeması kullanilırken, 15 (\%38.5) hastada esnek tedavi öncesinde ikili ve yoğun insülin tedavi şeması kullanıldığı ve tanıdan ortalama $21.07 \pm 31.65$ ay sonra esnek insülin tedavi rejimi başlandığı saptandı.

Esnek tedavi başlangıcında ortanca $\mathrm{HbA1c}$ düzeyi \%10.5 (6.418.5) olup, iyi metabolik kontrollü hasta sayısı 3 ile sınıllydı. Tedavi başlangıcında ortalama insülin dozu $0.87 \pm 0.25$ Ü/ $\mathrm{kg} /$ gündü. Tedavi başlangıcında olguların RA ortalaması $94.02 \pm 13.9$, BSDS ortalaması $-0.07 \pm 1.11$ olup, genetiğinde büyüyen çocuklardı. Çalışma döneminde tüm hastalar pubertal yaş grubunda olup, esnek tedavi başlangıcında prepubertal/ pubertal hasta oranı 17/22 saptandı. Tedavinin 1. yllında hastaların 21'inin (\%53.8) HbA1c düzeyi క\%7.5'e düştü, ancak 2. yılda 8 hastanın metabolik kontrolü bozuldu. Esnek insülin tedavisi ile 2 ylllkk izlemi devam ettirilen 39 olgunun izlem süresince ortalama HbA1c düzeyleri değerlendirildiğinde; 23

Tablo I: Hastaların tedavi öncesi klinik ve metabolik verileri.

\begin{tabular}{|c|c|c|c|c|}
\hline & $\begin{array}{l}\text { Tüm Grup } \\
(n=39)\end{array}$ & $\begin{array}{c}\text { Grup1 } \\
\text { HbA1c >\%7.5 } \\
(n=23)\end{array}$ & $\begin{array}{c}\text { Grup 2 } \\
\text { HbA1c } \leq \% 7.5 \\
(n=16)\end{array}$ & $\begin{array}{c}\text { p } \\
\text { Grup } \\
\text { 1-Grup 2 }\end{array}$ \\
\hline $\begin{array}{l}\text { Cinsiyet * } \\
\text { KIz } \\
\text { Erkek }\end{array}$ & $\begin{array}{l}21(\% 53.8) \\
18(\% 46.2)\end{array}$ & $\begin{array}{l}13(\% 56.5) \\
10(\% 43.5)\end{array}$ & $\begin{array}{l}8(\% 50) \\
8(\% 50)\end{array}$ & $>0.05$ \\
\hline Diyabet tanı yaşı (yıl) ${ }^{\dagger}$ & $9.19(3-16.44)$ & $7.17(3-13.29)$ & $10.07(4.43-16.44)$ & 0.046 \\
\hline 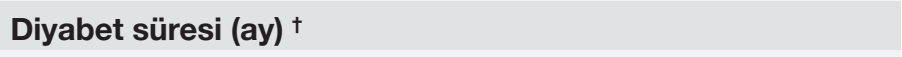 & $52(25-152)$ & $58(25-152)$ & $43(25-119)$ & $>0.05$ \\
\hline Esnek insülin tedavisine başlama yaşı (yıl) ₹ & $10.5 \pm 3.29$ & $10.12 \pm 3.64$ & $11.05 \pm 2.73$ & $>0.05$ \\
\hline Esnek tedavi öncesi diyabet süresi $(a y)^{\ddagger}$ & $21.07 \pm 31.65$ & $28.39 \pm 34.88$ & $10.5 \pm 23.51$ & $>0.05$ \\
\hline Esnek tedavi başlangıcında $\mathrm{HbA1c}(\%)^{\dagger}$ & $10.5(6.4-18.5)$ & $9.3(6.4-18.5)$ & $11.6(6.4-15.7)$ & 0.046 \\
\hline Esnek tedavi başlangıcında insülin dozu $(\mathrm{U} / \mathbf{k g} / \mathbf{g})^{\ddagger}$ & $0.87 \pm 0.25$ & $0.81 \pm 0.26$ & $0.95 \pm 0.21$ & $>0.05$ \\
\hline Esnek tedavi başlangıcında RA ‡ & $94.02 \pm 13.9$ & $96.89 \pm 15.59$ & $89.88 \pm 10.26$ & $>0.05$ \\
\hline Esnek tedavi başlangıcında BSDS * & $(-0.07) \pm 1.11$ & $(-0.21) \pm 1.01$ & $0.13 \pm 1.25$ & $>0.05$ \\
\hline Esnek tedavi başlangıcında genetiğe uyum & $0.04 \pm 1.14$ & $0.74 \pm 1.29$ & $0.91 \pm 0.9$ & $>0.05$ \\
\hline $\begin{array}{l}\text { Esnek tedavi başlangıcında pubertal gelişim Prepubertal/ } \\
\text { pubertal }\end{array}$ & $17 / 22$ & $11 / 12$ & $6 / 10$ & $>0.05$ \\
\hline
\end{tabular}

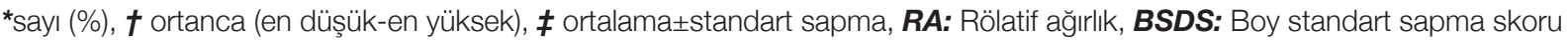


Tablo II: Hastaların 2 ylllkk izlemde antropometrik verileri.

\begin{tabular}{|c|c|c|c|c|c|c|c|}
\hline & Grup & $\begin{array}{c}\text { Tedavi } \\
\text { başlangıcı }\end{array}$ & 1. yıl & 2. yıl & $\begin{array}{c}\mathrm{p} \\
\text { (tedavi başlangıcı } \\
-1 . \text { yıl) } \\
\end{array}$ & $\begin{array}{c}\mathrm{p} \\
\text { (tedavi başlangıcı } \\
-2 \text {. yıl) } \\
\end{array}$ & $\begin{array}{c}p \\
\text { (1.-2. yıl) }\end{array}$ \\
\hline $\mathbf{R A}^{*}$ & $\begin{array}{l}\text { Tüm grup } \\
\text { Grup } 1 \\
\text { Grup } 2\end{array}$ & $\begin{array}{l}94.02 \pm 13.95 \\
96.89 \pm 15.59 \\
89.88 \pm 10.26\end{array}$ & $\begin{array}{c}97.45 \pm 11.1 \\
97.91 \pm 12.11 \\
96.77 \pm 9.81\end{array}$ & $\begin{array}{c}97.93 \pm 11.41 \\
98.97 \pm 13.74 \\
96.44 \pm 7.01\end{array}$ & $\begin{array}{l}>0.05 \\
>0.05 \\
0.016\end{array}$ & $\begin{array}{l}>0.05 \\
>0.05 \\
0.031\end{array}$ & $\begin{array}{l}>0.05 \\
>0.05 \\
>0.05\end{array}$ \\
\hline BSDS * & $\begin{array}{l}\text { Tüm grup } \\
\text { Grup } 1 \\
\text { Grup } 2\end{array}$ & $\begin{array}{c}(-0.07) \pm 1.11 \\
-0.21 \pm 1.01 \\
0.13 \pm 1.25\end{array}$ & $\begin{array}{c}-0.05 \pm 1.01 \\
-0.26 \pm 1.05 \\
0.26 \pm 0.89\end{array}$ & $\begin{array}{l}0.023 \pm 1.04 \\
-0.12 \pm 1.18 \\
0.22 \pm 0.77\end{array}$ & $\begin{array}{l}>0.05 \\
>0.05 \\
>0.05\end{array}$ & $\begin{array}{l}>0.05 \\
>0.05 \\
>0.05\end{array}$ & $\begin{array}{l}>0.05 \\
>0.05 \\
>0.05\end{array}$ \\
\hline Genetiğe Uyum * & $\begin{array}{l}\text { Tüm grup } \\
\text { Grup } 1 \\
\text { Grup } 2\end{array}$ & $\begin{array}{l}0.04 \pm 1.14 \\
0.07 \pm 1.29 \\
0.01 \pm 0.91\end{array}$ & $\begin{array}{l}0.089 \pm 1.00 \\
0.06 \pm 1.12 \\
0.13 \pm 0.82\end{array}$ & $\begin{array}{c}0.15 \pm 1.007 \\
0.19 \pm 1.18 \\
0.09 \pm 0.7\end{array}$ & $\begin{array}{l}>0.05 \\
>0.05 \\
>0.05\end{array}$ & $\begin{array}{l}>0.05 \\
>0.05 \\
>0.05\end{array}$ & $\begin{array}{l}>0.05 \\
>0.05 \\
>0.05\end{array}$ \\
\hline $\begin{array}{l}\text { Pubertal gelişim } \\
\text { Prepubertal/pubertal }\end{array}$ & $\begin{array}{l}\text { Tüm grup } \\
\text { Grup } 1 \\
\text { Grup } 2\end{array}$ & $\begin{array}{l}17 / 22 \\
11 / 12 \\
6 / 10\end{array}$ & $\begin{array}{l}15 / 24 \\
11 / 12 \\
4 / 12\end{array}$ & $\begin{array}{l}12 / 27 \\
9 / 14 \\
3 / 13\end{array}$ & $\begin{array}{l}>0.05 \\
>0.05 \\
>0.05\end{array}$ & $\begin{array}{l}>0.05 \\
>0.05 \\
>0.05\end{array}$ & $\begin{array}{l}>0.05 \\
>0.05 \\
>0.05\end{array}$ \\
\hline
\end{tabular}

* ortalama \pm standart sapma, RA: Rölatif ağırlı, BSDS: Boy standart sapma skoru

Tablo III: Hastaların 2 yıllık izlemde akut komplikasyon ve metabolik parametreleri.

\begin{tabular}{|c|c|c|c|c|c|}
\hline & Komplikasyon & Tüm Grup (n=39) & $\begin{array}{l}\text { Grup } 1(n=23) \\
\text { HbA1c }>\% 7.5\end{array}$ & $\begin{array}{l}\text { Grup } 2(n=16) \\
\text { HbA1c } \leq \% 7.5\end{array}$ & $\stackrel{p}{\text { Grup } 1-2}$ \\
\hline Akut komplikasyonlar & $\begin{array}{l}\text { Ciddi hipoglisemi Atak sayısı/100 hasta-yıl } \\
\text { DKA Atak sayısı/100 hasta-yıl }\end{array}$ & $\begin{array}{l}7.7 \\
6.4\end{array}$ & $\begin{array}{c}8.7 \\
10.86\end{array}$ & $\begin{array}{c}6.2 \\
0\end{array}$ & $\begin{array}{l}>0.05 \\
>0.05\end{array}$ \\
\hline $\begin{array}{l}\text { Metabolik ve sağlık } \\
\text { parametreleri }\end{array}$ & $\begin{array}{l}\text { Trigliserid * } \\
\text { Total kolesterol * } \\
\text { HDL * } \\
\text { LDL * }^{*} \\
\text { VLDL * } \\
\text { Aterojenik İndeks } † \\
\text { TG/HDL † } \\
\text { Bazal sistolik kan basıncl * } \\
\text { Bazal diastolik kan basıncl * }\end{array}$ & $\begin{array}{c}96.82 \pm 58.97 \\
166 \pm 40 \\
53 \pm 15 \\
92.5 \pm 30.6 \\
19.10 \pm 11.92 \\
3.03(2.1-6.3) \\
1.54(0.6-7.75) \\
102 \pm 7.8 \\
64 \pm 7.7\end{array}$ & $\begin{array}{c}105.71 \pm 6.36 \\
168 \pm 45 \\
51 \pm 15 \\
93 \pm 36 \\
21.64 \pm 14.21 \\
3.08(2.2-6.3) \\
1.88(0.6-7.7) \\
102 \pm 6.2 \\
65.8 \pm 6.78\end{array}$ & $\begin{array}{c}84.03 \pm 38.18 \\
163 \pm 32 \\
56 \pm 15 \\
90 \pm 21 \\
15.45 \pm 6.33 \\
2.82(2.1-4) \\
1.37(0.6-5.9) \\
102 \pm 10 \\
63.2 \pm 9\end{array}$ & $\begin{array}{l}>0.05 \\
>0.05 \\
>0.05 \\
>0.05 \\
>0.05 \\
>0.05 \\
>0.05 \\
>0.05 \\
>0.05\end{array}$ \\
\hline $\begin{array}{l}\text { Enjeksiyon yeri } \\
\text { komplikasyonları }\end{array}$ & $\begin{array}{l}\text { Kanama } \ddagger \\
\text { Ağrı } \ddagger \\
\text { Hipersensitivite } \ddagger \\
\text { Lipohipertrofi } \ddagger \\
\text { CK yüksekliği } \ddagger\end{array}$ & $\begin{array}{c}9 / 31(\% 29) \\
6 / 31(\% 19.4) \\
2 / 31(\% 6.5) \\
31 / 38(\% 81.5) \\
2 / 39(\% 5.1)\end{array}$ & $\begin{array}{c}6 / 18(\% 33.3) \\
3 / 18(\% 16.7) \\
1 / 18(\% 5.6) \\
18 / 22(\% 81.8) \\
2 / 23(\% 8.7)\end{array}$ & $\begin{array}{c}3 / 13(\% 23.1) \\
3 / 13(\% 23.1) \\
1 / 13(\% 7.7) \\
13 / 16(81.2) \\
0 / 16(\% 0)\end{array}$ & $\begin{array}{l}>0.05 \\
>0.05 \\
>0.05 \\
>0.05 \\
>0.05\end{array}$ \\
\hline
\end{tabular}

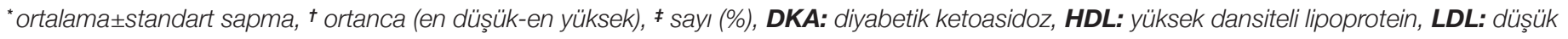
dansiteli lipoprotein, VLDL: çok düşük dansiteli lipoprotein, TG: trigliserid, CK: Kreatin kinaz

(\%59)'ünün >\%7.5 olduğu (Grup 1), 16 (\%41)'sının $\leq \% 7.5$ olduğu (Grup 2) görüldü. İki grup arasında esnek tedaviye başlama yaşı benzerdi ( $\mathrm{p}>0.05)$. Grup 2'deki hastalara Grup 1'e göre diyabet tanısından daha kısa süre sonra esnek insülin tedavisi başlanmasına rağmen, fark istatistiksel anlamlı değildi (grup 1 ve grup 2 için esnek tedavi öncesi diyabet süresi sirasiyla $28.39 \pm 34.88$ ve $10.5 \pm 23.51$ ay, $p>0.05$ ). Grup 2'deki hastaların başlangıç HbA1c düzeyleri daha kötüydü ( $p=0.046$ ). Tedavi başlangııında gruplar arasında ortalama insülin dozu, RA, BSDS, genetiğe uyum ve pubertal/prepubertal oranı benzerdi.

Hastaların 2 yllık izlemde ortanca HbA1c düzeylerinin seyri Şekil 1'de görülmektedir. Esnek tedavi başlangıcında tüm grupta ortanca HbA1c düzeyi \% 10.5 (6.4-18.5) iken, tedavinin 1. yllında
\%7.4 (5.2-11.7)'e düştü $(\mathrm{p}<0.001)$, tedavinin 2. yllında ise, 1. yıla göre artarak \% $8.2(5.8-12.4)$ 'ye yükseldi $(p<0.01)$. Esnek insülin tedavisinin 1. yllında grup 1'in ortanca $\mathrm{HbA} 1 \mathrm{c}$ düzeyi \% 9.3 (6.4-18.5)'ten \%8.1 (6.5-11.7)'e düşerken $(p<0.05)$, tedavinin 2. yllında, 1. yıla göre artarak \%8.6 (7.6-12.4)'ya yükseldi $(p<0.01)$. Tüm grubun ve grup 1 'in tedavi başlangıcına göre, izlemin 2. yllı sonunda ortanca HbA1c düzeyleri değişmedi ( $p>0.05$ ). Grup 2'de tedavinin 1. ylında HbA1c düzeyi \%11.6 (6.4-15.7)'dan \%6.7 (5.2-7.4)'ye düştü $(p<0.001)$, tedavinin 2. yllında ise ortanca HbA1c düzeyi \%7 (5.8-8.4) olup, tedavinin 1. yllı ile benzer şekilde düşük seyretti ( $p>0.05)$.

Grup 1, grup 2 ve tüm grubun antropometrik verileri Tablo Il'de görülmektedir. Esnek insülin tedavisi ile 2 ylllık izlemi sürdürülen tüm hastalar değerlendirildiğinde, tedavi başlangıcına göre rölatif 
Tablo IV: Hastaların tedaviye uyum özellikleri.

\begin{tabular}{|c|c|c|c|c|}
\hline & Tüm grup & $\begin{array}{c}\text { Grup } 1(\mathrm{n}=23) \mathrm{HbA1c} \\
>\% 7.5\end{array}$ & $\begin{array}{c}\text { Grup } 2(\mathrm{n}=16) \mathrm{HbA1c} \\
\leq \% 7.5\end{array}$ & $\begin{array}{c}p \\
\text { (Grup 1-Grup 2) }\end{array}$ \\
\hline Karbonhidrat sayımı & $15 / 30(\% 50)$ & 6/18 (\%33.3) & $9 / 12(\% 75)$ & 0.025 \\
\hline Hazır yemek (fast food) tüketimi & $11 / 30(\% 36.7)$ & 10/18 (\%55.6) & 1/12 (\%8.3) & 0.018 \\
\hline Gazlı içecek tüketimi & $11 / 30(\% 36.7)$ & $9 / 18(\% 50)$ & 2/12 (\%16.7) & $>0.05$ \\
\hline
\end{tabular}

ağırlıkta istatistiksel anlamlı fark bulunmadı ( $p>0.05$ ). Gruplar tek tek ele alındığında, grup 1'de RA'da tedavi başlangıcına göre, tedavinin 1. yllında ve 2. yllında anlamlı bir fark saptanmazken ( $p>0.05)$, grup 2'de tedavinin başlangıcına göre 2 yıllık izlemin sonunda RA'da anlamlı artış saptandı $(p=0.031)$. Bu artış esnek insülin tedavisinin 1. ylında olup $(p=0.016), 1$. ve 2. yıl arasında RA'lar benzerdi ( $p>0.05)$. 2 ylllik izlem sonucunda sadece 1 (\%2.5) hastada esnek tedavinin 2. yllinda obezite geliştiği görüldü; obezite gelişen olgu, kötü metabolik kontrol grubundandı. Geri kalan 38 olgunun rölatif ağırlıkları idealdi. Grup 1, grup 2 ve tüm grubun BSDS'leri ve genetiğe uyumları değerlendirildiğinde, tedavi başlangııına göre esnek insülin tedavisinin 1. ve 2. ylında istatistiksel anlamlı bir fark saptanmadı (p>0.05). Esnek tedavi bașlangııında grup 1'deki olguların \%52.2'si, grup 2'deki olguların \%62.5'i pubertal dönemde iken; 2 yillık esnek insülin tedavisi sonunda grup 1'deki olguların \%60.9'u, grup 2'deki olguların \%81.3'ü pubertal dönemdeydi. Tedavi sonunda gruplar arasında pubertal dönemdeki olguların sıklı̆ı̆ açısından istatistiksel anlamlı fark saptanmadı ( $p>0.05$ ).

Esnek tedavi alan tüm hastalar değerlendirildiğinde tedavi başlangıcına göre izlemin 2. ylında, ortalama insülin dozlarının $0.87 \pm 0.25 \quad$ Ü/ $/ \mathrm{kg} / g u ̈ n ' d e n, \quad 0.97 \pm 0.25 \quad$ Ü/ $\mathrm{kg} / g u ̈ n ' e$ arttığı saptandı ( $\mathrm{p}<0.001)$. Grup 1'de tedavi bașlangıcında ortalama insülin dozu $0.81 \pm 0.26$ Ü/kg/gün iken izlemin 2. yilı sonunda

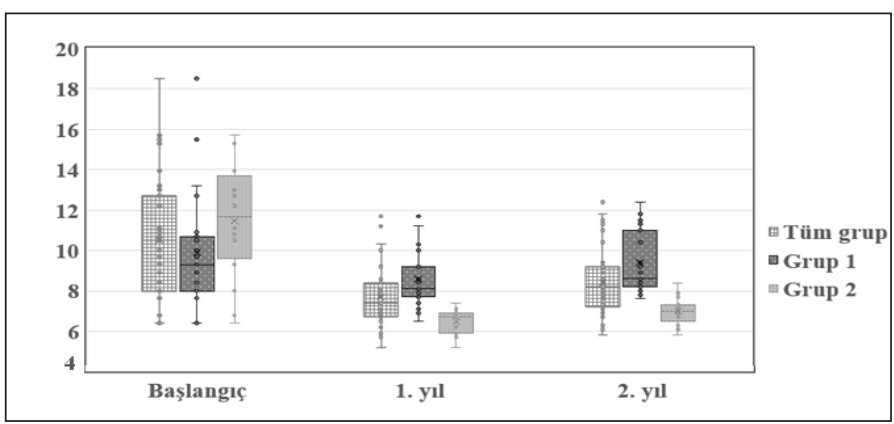

Şekil 1: Hastaların HbA1c düzeylerinin seyri.

- Esnek tedavinin başlangıcı ile tedavinin 1. yılı karşılaştıııldığında tüm grup, grup 1, ve grup 2'de, HbA1c düzeyinde anlamlı bir düșme (sırasıyla $p<0.01, p<0.005$ ve $p<0.001$ ) saptandı.

- Tedavinin 2. ylında, tedavinin 1. yllına göre HbA1c düzeyinin tüm grupta ve grup 1'de arttığı (sırasıyla $p<0.01$ ve $p<0.001$ ), grup 2 'de ise benzer seyrettiği saptandı ( $p>0.05$ ).

- Esnek tedavi bașlangıcı ile tedavinin 2. yılı karșılaștııılığında HbA1c düzeylerinde tüm grup ve grup 1'de fark saptanmazken ( $>>0.05)$, grup 2'de anlamlı azalma saptandı ( $<<0.01)$. ortalama insülin dozunun $1 \pm 0.3$ Ü/kg/gün'e arttığı ( $p=0.002)$, bu artışın özellikle tedavinin 2. ylında olduğu gözlendi ( $p=0.001$ ). Grup 2'de ise, esnek tedavi bașlangııında ortalama insülin dozu $0.95 \pm 0.21 \mathrm{Ü} / \mathrm{kg} / \mathrm{gün}$ iken izlemin 1. yllında ortalama insülin dozunda $0.81 \pm 0.19 \mathrm{U} / \mathrm{kg} / \mathrm{gün}$ 'e azalma $(p=0.031)$, 2. yllında ise $0.91 \pm 0.18 \mathrm{U} / \mathrm{kg} /$ gün'e artma saptandı $(\mathrm{p}=0.04)$, ancak tedavi bașlangııına göre izlemin 2. ylında ortalama insülin dozu değișmedi ( $p>0.05)$.

İki yıl esnek insülin tedavisi sonrası gruplar arasında ortalama insülin dozu, RA, BSDS, genetiğe uyum açısından anlamlı fark saptanmadı $(p>0.05)$.

Hastaların metabolik ve sağılı parametrelerine ait veriler Tablo III'de görülmektedir. Gruplar arasında ciddi hipoglisemi ve DKA atak sıklığı açısından fark saptanmadı ( $p>0.05)$. Otuz dokuz hastanın 6'sında (\%15.3) dislipidemi saptandı. Grup 1'deki trigliserid, total kolesterol, LDL, VLDL düzeyleri grup 2'den daha yüksek, HDL düzeyi ise daha düşük olmasına rağmen, istatistiksel anlamlı fark saptanmadı $(p>0.05)$. Dislipidemi gelişen hastaların ortanca diyabet süresi, dislipidemi gelişmeyen hastalara göre daha uzundu (sırasıyla 87 (24-120) ay ve 24 (24126) ay, $p=0.018$ ). Dislipidemi gelişen ve gelişmeyen hastalarda HbA1c düzeyleri benzerdi. Gruplar arasında bazal sistolik ve diastolik kan basıncı ortalamaları benzerdi. Enjeksiyon yeri komplikasyonları açııından gruplar arasında fark saptanmadı (Tablo III).

Grup 2'de karbonhidrat sayımı uygulaması $(\mathrm{p}=0.025)$ ve diyet uyumu ( $p=0.038$ ) istatistiksel olarak anlamlı yüksek, hazır yemek tüketimi daha azdı ( $p=0.018$ ) (Tablo IV).

\section{TARTIŞMA}

Bu çalışmada, esnek insülin tedavisinin diyabetli çocuk ve ergenlerde vücut ölçümleri ile glisemik ve metabolik kontrol üzerindeki etkileri araştırıld. Çalışmamızda esnek insülin tedavisinin, sağlıkı beslenen ve karbonhidrat sayımı yapan çocuklarda, RA'da anormal artış yapmadığı ve HbA1c düzeyini $\leq \% 7.5$ 'e düşürdüğü saptandı.

Çalışmamızdaki hastaların cinsiyet dağılımı, tanı yașları, tanıda DKA ile başvuru sıkığı, otoimmün tiroidit ve çölyak hastalığı sıklığı literatürle benzerdi (12-17). 
Çocuk ve adolesanlarda esnek öğün ve insülin tedavisinin HbA1c üzerindeki etkilerini değerlendiren çalışmalar az sayıda hasta grubunda yapılması ve kısa süreli izlem çalışmaları olmaları nedeniyle sınırıdır. Literatürde esnek insülin tedavisi ile, tedavi öncesine göre tedavinin 1. yll sonunda $\mathrm{HbA} 1 \mathrm{c}$ düzeylerini karşılaştıran çalışmaların bazılarında HbA1c düzeyinin azaldığı bildirilirken, diğer çalışmalarda $\mathrm{HbA1c}$ düzeyinin arttığı ya da değişmediği belirtilmiştir (18-22). Esnek insülin tedavisinin $\mathrm{HbA1c}$ düzeyine etkisi ile ilgili çocuklarda randomize kontrollü bir çalışmada esnek insülin tedavisi ve karbonhidrat sayımının HbA1c düzeylerini düşürdüğü gösterilmiştir (23). Çalışmamızda esnek insülin tedavisinin 1. yllında HbA1c'de istatistiksel anlamlı bir düşüş sağlandığl; olguların \%53.8'inin $\mathrm{HbA1c}$ düzeylerinin hedef değer olan \%7.5'in altına düştüğü saptandı. Tedavinin 2. yllında ise hastaların sadece $\% 33$ 'ünün $\mathrm{HbA} 1 \mathrm{c}$ düzeyinin hedef değerin altında olduğu ve ikinci yilda metabolik kontrolün bozulduğu görüldü. Kadlubiska ve ark. (24) retrospektif araştırmalarında, esnek insülin tedavisi alan hastalarda tanıdan itibaren 5 ylllık izlemde glisemik kontrolün giderek kötüleştiğini

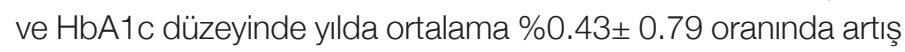
olduğunu göstermişlerdir. Çalışmamızda hasta sayımız daha az ve izlem süresi daha kısa olmasına rağmen, sonuçlarımız Kadlubiska ve ark. (24) çalışmasını destekler şekilde, önce iyi bir düzelme gösterse de 2. yll izleminde görüldüğü gibi diyabet süresi uzadıkça metabolik kontrolün bozulduğunu göstermektedir.

Kanıtlar, karbonhidrat sayımının metabolik kontrolü sağlamada ve $\mathrm{HbA1c}$ konsantrasyonunu azaltmada olumlu etkileri olduğunu göstermektedir $(23,25)$. Zayıf diyet uyumunun kötü glisemik kontrolle ilişkili olduğu bilinmektedir (26). Çalışmamızda literatürle benzer şekilde grup 2'deki hastalar diyet uyumu olan ve karbonhidrat sayımı yapan hastalardı.

Çalışmamızda grup 2'deki olguların esnek tedavi başlangıcında HbA1c düzeyi, grup 1'den daha yüksekti. Bu bulgu bazal bolus tedavi sonrası $\mathrm{HbA} 1 \mathrm{c}$ düzeyinde en fazla iyileşmenin, başlangıç metabolik kontrolü daha kötü olan hastalarda gözlendiğini belirten önceki çalışmalarla uyumluydu $(27,28)$.

Çalışmamızda Hochhauser ve ark. (29) çalısmasına benzer şekilde, cinsiyetin glisemik kontrol üzerine etkisi saptanmadı.

Normal lineer büyümenin sağlanması, çocuk ve ergenlerde diyabetin yönetiminde en önemli tedavi hedeflerinden biridir. Tip 1 diyabetli çocuk ve ergenlerin büyümesine ilişkin literatürde farklı veriler mevcuttur. Diyabetli hastalarda, özellikle ergenlik döneminde GH/IGF-1 aksında, GH hipersekresyonu, serum IGF-1 ve IGFBP-3 düzeyinde azalma ve IGFBP-1 seviyelerinde artış ile karakterize değişiklikler olduğu gösterilmiştir (30). Bu çocukların, sağlıklı çocuklara göre büyüme hızlarının daha düşük olduğu zayıf glisemik kontrolün ve uzun hastalık süresinin, diyabetli ergenlerde boy uzamasında azalma ile ilişkili olduğu gösterilmiştir (12,31-33). Erişkin boyun ortalama HbA1c düzeyi $<\% 7$ 'nin altında olan hastalarda normal olduğu, ancak orta (HbA1c \%7-8) ve kötü (HbA 1c >\%8) glisemik kontrollü hastalarda daha az olduğu bildirilmiştir (12). Ancak, en yeni veriler modern yoğun insülin tedavileri ile diyabetli çocukların normal final boya ulaştığını göstermiştir (6). Yakın geçmişte yapılan bir araştırmada, bazal-bolus tedavisi alan hastaların geleneksel tedavi alan hastalardan daha iyi metabolik kontrole ve daha yüksek bir büyüme hızına sahip oldukları gösterilmiştir (31). Çalışmamızda esnek insülin tedavisi alan hastaların 2 yllık izlemde boy SDS seyrinde tedavi başlangıcına göre anlamlı fark saptanmadı. Grup 2'deki olguların boy SDS'leri grup 1'den daha iyi olmakla birlikte, fark istatistiksel anlamlı bulunmadı.

Kısa izlem süreli çalsşmalarda, karbonhidrat sayımına dayanan esnek insülin tedavisinin VKI'yi ve vücut kitle indeksi standart sapma skorunu (VKI-SDS) değişmediği; uzun izlem süreli çalışmalarda ise VKI-SDS'yi ve obezite prevalansını arttırdığı saptanmıştır $(18,23,24,34,35)$. Çalışmamızda esnek insülin tedavisi ile 2 ylllık izlemi sürdürülen tüm olgular değerlendirildiğinde, kısa izlem süreli önceki çalışmalara benzer şekilde, tedavi başlangıcına göre rölatif ağırlığın değişmediği saptandı. Kilo alımının metabolik kontrolle ilişkisini değerlendiren Kadlubiska ve ark.(24) HbA1c düzeyi ve VKi-SDS arasında istatistiksel anlamlı ilişki saptamamışlardır (18,22,23). Aksine Högel ve ark. (36) iyi metabolik kontrolü, VKi'de artışla ilişkilendirmişlerdir. Çalışmamızda Högel ve ark. (36) çalışmasına benzer şekilde, 2 yillik izlemde, grup 1'de RA sabit seyir gösterirken; grup 2'nin esnek tedavi başlangıcına göre, izlemin 2. yilı sonunda RA'da anlamlı artış saptandı.

Kadlubiska ve ark.(24) ortanca tanı yaşı 8.71 (6.42-11.67) olan, esnek insülin tedavisi alan çocukların tanıdan sonraki 5 yllık izlem boyunca günlük insülin dozunun 0.56 'dan 0.89 Ü/kg/gün 'e anlamlı artış gösterdiğini ortaya koymuştur. Üç ila yirmi beş yaş arası yoğun insülin tedavisi alan 22177 hastada yapılan bir çalışmada günlük insülin dozu en düşük 3 yaşta (0.67 Ü/kg/gün) ve en yüksek 13 yaşta (0.93 Ü/kg/gün) saptanmıştı (37). Bloch ve ark. (38), pubertede insülin duyarlıığının azaldığını, bunun normalde artan insülin sekresyonu ile kompanse edildiğini ve bu nedenle tip 1 diyabetli hastalarda puberte başlangıcı ile insülin dozunda yaklaşık \%30 artış olduğunu bildirmişlerdir. Benzer şekilde Demir ve ark. (39) insülin intiyacının pubertal ve postpubertal dönemde arttı̆ı̆ı göstermişlerdir. Bizim çalışmamızda tüm grubu ele aldığımızda olguların esnek tedaviye başlama yaş ortalaması $10.5 \pm 3.29$ ' du. İki yllık esnek insülin tedavisi sonunda olguların ortalama insülin dozlarında anlamlı artış saptandı. Bu artış özellikle de izlemin 1. yilı ve 2. yılı arasındaydı. Bu artışın, olguların yaşlarının büyümesiyle, puberteye giren olguların sayısının artması ya da pubertedeki olguların pubertelerinin ilerlemesi nedeniyle insülin intiyacının artmasına bağlı olabileceği düşünüldü.

Puberte öncesi diyabeti başlayanlarda, sağlıklı çocuklara göre 
pubertenin geciktiği, pubertede zirve büyüme hızlanmasının ve toplam boy kazancının daha düşük olduğu ve puberte öncesi daha uzun diyabet süresinin ve yüksek $\mathrm{HbA1c}$ düzeylerinin pubertenin daha geç yaşta başlaması ile ilişkili olduğu bildirilmiştir (40-42). Çalışmamızda esnek tedaviye başlama yașı grup 1' de 10.12 \pm 3.64 iken, grup 2'de $11.05 \pm 2.73$ olup, benzerdi. İki ylllık esnek insülin tedavisi sonrasında istatistiksel olarak anlamlı olmasa da grup 2'deki hastaların daha fazla oranda pubertal dönemde olduğu saptandı. Grupların tanı yașları değerlendirildiğinde grup 1 'in tanı yașı $7.79 \pm 3.72$, grup 2'nin tanı yașı 10.2 23.35 olup; grup 1'deki olguların daha erken yaşta tanı aldığı ve puberte öncesi diyabet sürelerinin literatürle uyumlu olarak, bu olgularda daha uzun olduğu görüldü.

Ciddi hipoglisemi insülin tedavisinin en yaygın akut komplikasyonlarından biridir ve başarılı glisemik kontrolü sınılayan temel faktördür. Esnek insülin tedavisi öncesini ve sonrasını karşılaşııran araştırmalarda diyabetli çocuklarda ciddi hipoglisemi sıklığında azalma belirtilmiştir $(18,43)$. Diyabet Kontrolü ve Komplikasyonları Çalıșması'nda (DCCT) yoğun tedavi alan adolesanlarda ciddi hipoglisemi insidansı 100 hasta ylında 26.7 atak olarak yayınlanmışıı (44). Blasetti ve ark. (11) prospektif çalıșmalarında ciddi hipoglisemi insidansını 100 hasta yılında 9,4 atak olarak saptamışlardır. Çalışmamızda ciddi hipoglisemi atak sıkliğı, DCCT Çalışması'ndan düşük, Blasetti ve ark. (11) çalıșmasına benzer şekilde, 100 hasta yllında 7.7 atak olarak saptandı. Gerçi silik hipoglisemik atakların, hem poliklinik değerlendirmesinde, hem de aile tarafindan kayıtlarının yeteri kadar iyi tutulmamış olabileceği kanısındayız. Bu nedenle sonuçlarımı daha çok ciddi hipoglisemi atağını yansıtmaktadır. Ciddi hipoglisemi ile glisemik kontrol ilişkisi değerlendirildiğinde ise, DCCT Çalışması daha iyi glisemik kontrolün ciddi hipoglisemi riskinde artışa neden olduğunu, buna karşın Levine ve ark.(46) prospektif çalışmalarında kötü metabolik kontrollü olgularda ciddi hipoglisemi insidansının daha yüksek olduğunu bildirmişlerdir (45). Aksine Blasetti ve ark. (11) ciddi hipogliseminin HbA1c düzeyi ile ilişkisiz olduğunu ileri sürmüşlerdir. Çalışmamızda Blasetti ve ark. (11) çalışmasına benzer şekilde grup 1 ve grup 2 arasında hipoglisemi atak sıklığında fark saptanmadı.

Otuz bin hastada yapılan çok merkezli bir çalıșmada DKA atak sıkığı 100 hasta ylında 5.9 atak olarak bildirilmiştir. Bu çalıșmadaki olguların \%10.1'i geleneksel tedavi alan, \%65'i yoğun tedavi alan, \%24.9'u ise insülin pompası kullanan hastalardı (47). Çalışmamızda DKA atak sıkı̆̆ı 100 hasta ylında 6.4 atak olup, literatüre benzerdi.

Guy ve ark. (48) tip 1 diyabetli gençlerde, glisemik kontrolün ortalama lipid düzeyleri üzerinde ve lipid anormalliklerinin prevalansında önemli ölçüde etkili olduğunu ileri sürmüşlerdir. Gökçen ve ark. (23) karbonhidrat sayımı yapan tip 1 diyabetli çocuklarda HDL düzeylerinin kontrol grubundan yüksek olduğunu ve bu durumun karbonhidrat sayımı yapan hastaların sağlkklı ve dengeli beslenme konusunda artan bilgisine bağlı olabileğini ortaya koymuştur. Çalışmamızda grup 1'deki trigliserid, total kolesterol, LDL, VLDL düzeyleri grup 2'den daha yüksek, HDL düzeyi ise daha düșük olmasına rağmen bu fark istatistiksel olarak anlamlı bulunmadı. Ancak sonuçların literatür ile benzer olduğunu düșünmekteyiz.

Çalıșmamız tip 1 diyabetli olguların esnek insülin tedavisinde 2 yıllık izlem sonuçlarını değerlendiren longitidunal bir çalışma olması açısından değerlidir. Ancak hasta sayısının az olması ve izlem süresinin kısa olması çalışmanın en önemli kısıtlıığıdır.

Sonuç olarak, esnek insülin tedavisi alan olguların 2 yillık takip sonuçlarını değerlendirdiğimiz çalıșmamızdaiyi kontrolü sürdüren olguların etkili karbonhidrat sayımı yapabilen, beslenme uyumu daha iyi olan, pubertal yașta olgular olduğu görüldü. Esnek insülin tedavisinin RA'da anormal artış yapmadan glisemik kontrolü düzelttiği, HbA1c düzeyini $\leq \% 7.5$ 'e düşürdüğü ve dolayısıyla metabolik komplikasyonları iyileştirdiği saptandı. Ancak diyabet süresi uzadıkça bu durumu korumakta zorlandıkları gözlendi. Tüm grupta esnek insülin tedavisi ile HbA1c düzeyinde iyileșme olmasına karşın, hala kötü kontrole sahip olanlarda beslenme konusunda daha etkin davranıș değișikliğine gereksinim olduğu kanısındayız.

\section{KAYNAKLAR}

1. Diabetes C, Complications Trial Research G, Nathan DM, Genuth $S$, Lachin J, Cleary P, et al. The effect of intensive treatment of diabetes on the development and progression of long-term complications in insulin-dependent diabetes mellitus. N Engl J Med 1993; 329: 977-86.

2. Kawamura T. The importance of carbohydrate counting in the treatment of children with diabetes. Pediatr Diabetes 2007; 8 Suppl 6: 57-62.

3. Norris A, Wolfsdorf Jl. Brook's Clinical Pediatric Endocrinology. NJ, USA: Wiley-Blackwell 2009:458-504

4. Neu A, Lange K, Barrett $T$, Cameron F, Dorchy $H$, Hoey $H$, et al. Classifying insulin regimens--difficulties and proposal for comprehensive new definitions. Pediatr Diabetes 2015; 16: 402-6.

5. Schmidt S, Schelde B, Norgaard K. Effects of advanced carbohydrate counting in patients with type 1 diabetes: a systematic review. Diabet Med 2014; 31: 886-96.

6. Bizzarri C, Timpanaro TA, Matteoli MC, Patera IP, Cappa M, Cianfarani S. Growth Trajectory in Children with Type 1 Diabetes Mellitus: The Impact of Insulin Treatment and Metabolic Control. Horm Res Paediatr 2018; 89: 172-7.

7. Franc S, Dardari D, Boucherie B, Riveline JP, Biedzinski M, Petit C, et al. Real-life application and validation of flexible intensive insulintherapy algorithms in type 1 diabetes patients. Diabetes Metab 2009; 35: 463-8.

8. Gokcay G, Furman A, Neyzi O. Updated growth curves for Turkish children aged 15 days to 60 months. Child Care Health Dev 2008; 34: 454-63. 
9. Neyzi O, Furman A, Bundak R, Gunoz H, Darendeliler F, Bas F. Growth references for Turkish children aged 6 to 18 years. Acta Paediatr 2006; 95: 1635-41.

10. Chiang JL, Kirkman MS, Laffel LM, Peters AL, Type 1 Diabetes Sourcebook A. Type 1 diabetes through the life span: a position statement of the American Diabetes Association. Diabetes Care 2014; 37: 2034-54.

11. Blasetti A, Di Giulio C, Tocco AM, Verrotti A, Tumini S, Chiarelli F, et al. Variables associated with severe hypoglycemia in children and adolescents with type 1 diabetes: a population-based study. Pediatr Diabetes 2011; 12: 4-10.

12. Bonfig W, Kapellen T, Dost A, Fritsch M, Rohrer T, Wolf J, et al. Growth in children and adolescents with type 1 diabetes. J Pediatr 2012; 160: 900-3 e2.

13. Chemtob CM, Hochhauser CJ, Shemesh E, Schmeidler J, Rapaport R. Does poor early metabolic control predict subsequent poor control in young children with type 1 diabetes: an exploratory study. J Diabetes 2011; 3: 153-7.

14. Dabelea D, Rewers A, Stafford JM, Standiford DA, Lawrence JM, Saydah S, et al. Trends in the prevalence of ketoacidosis at diabetes diagnosis: the SEARCH for diabetes in youth study. Pediatrics 2014; 133: e938-45.

15. Karaguzel G, Simsek S, Deger O, Okten A. Screening of diabetes, thyroid, and celiac diseases-related autoantibodies in a sample of Turkish children with type 1 diabetes and their siblings. Diabetes Res Clin Pract 2008; 80: 238-43.

16. Warncke K, Frohlich-Reiterer EE, Thon A, Hofer SE, Wiemann D, Holl RW, et al. Polyendocrinopathy in children, adolescents, and young adults with type 1 diabetes: a multicenter analysis of 28,671 patients from the German/Austrian DPV-Wiss database. Diabetes Care 2010; 33: 2010-2.

17. Xin Y, Yang M, Chen XJ, Tong YJ, Zhang LH. Clinical features at the onset of childhood type 1 diabetes mellitus in Shenyang, China. $J$ Paediatr Child Health 2010; 46: 171-5.

18. Alemzadeh R, Berhe T, Wyatt DT. Flexible insulin therapy with glargine insulin improved glycemic control and reduced severe hypoglycemia among preschool-aged children with type 1 diabetes mellitus. Pediatrics 2005; 115: 1320-4.

19. Adhikari S, Adams-Huet B, Wang YC, Marks JF, White PC. Institution of basal-bolus therapy at diagnosis for children with type 1 diabetes mellitus. Pediatrics 2009; 123: e673-8.

20. Hayes RL, Garnett SP, Clarke SL, Harkin NM, Chan AK, Ambler GR. A flexible diet using an insulin to carbohydrate ratio for adolescents with type 1 diabetes - a pilot study. Clin Nutr 2012; 31: 705-9.

21. Alemzadeh R, Ellis JN, Holzum MK, Parton EA, Wyatt DT. Beneficial effects of continuous subcutaneous insulin infusion and flexible multiple daily insulin regimen using insulin glargine in type 1 diabetes. Pediatrics 2004; 114: e91-5.

22. Paivarinta $M$, Tapanainen $P$, Veijola $R$. Basal insulin switch from $\mathrm{NPH}$ to glargine in children and adolescents with type 1 diabetes. Pediatr Diabetes 2008; 9: 83-90.

23. Goksen D, Atik Altinok Y, Ozen S, Demir G, Darcan S. Effects of carbohydrate counting method on metabolic control in children with type 1 diabetes mellitus. J Clin Res Pediatr Endocrinol 2014; 6: 74-8.

24. Kadlubiska A, Malachowska B, Noiszewska K, Fendler W, Glowinska-Olszewska B, Bossowski A, et al. Five-year observation of the relationship between body mass index and glycated hemoglobin in children with Type 1 diabetes mellitus. Scand J Clin Lab Invest 2018; 78: 398-406.
25. Fu S, Li L, Deng S, Zan L, Liu Z. Effectiveness of advanced carbohydrate counting in type 1 diabetes mellitus: a systematic review and meta-analysis. Sci Rep 2016; 6: 37067.

26. Patton SR, Dolan LM, Powers SW. Dietary adherence and associated glycemic control in families of young children with type 1 diabetes. J Am Diet Assoc 2007; 107: 46-52.

27. Colino E, Lopez-Capape M, Golmayo L, Alvarez MA, Alonso M, Barrio R. Therapy with insulin glargine (Lantus) in toddlers, children and adolescents with type 1 diabetes. Diabetes Res Clin Pract 2005; 70: 1-7.

28. Jackson A, Ternand C, Brunzell C, Kleinschmidt T, Dew D, Milla $C$, et al. Insulin glargine improves hemoglobin $A 1 C$ in children and adolescents with poorly controlled type 1 diabetes. Pediatr Diabetes 2003; 4: 64-9.

29. Hochhauser CJ, Rapaport R, Shemesh E, Schmeidler J, Chemtob $\mathrm{CM}$. Age at diagnosis, gender, and metabolic control in children with type 1 diabetes. Pediatr Diabetes 2008; 9: 303-7.

30. Munoz MT, Barrios V, Pozo J, Argente J. Insulin-like growth factor I, its binding proteins 1 and 3 , and growth hormone-binding protein in children and adolescents with insulin-dependent diabetes mellitus: clinical implications. Pediatr Res 1996; 39: 992-8.

31. Parthasarathy L, Khadilkar V, Chiplonkar S, Khadilkar A. Longitudinal Growth in Children and Adolescents with Type 1 Diabetes. Indian Pediatr 2016; 53: 990-2.

32. Mao L, Lu W, Ji F, Lv S. Development and linear growth in diabetic children receiving insulin pigment. J Pediatr Endocrinol Metab 2011; 24: 433-6.

33. Plamper M, Gohlke B, Woelfle J, Konrad K, Rohrer T, Hofer S, et al. Interaction of Pubertal Development and Metabolic Control in Adolescents with Type 1 Diabetes Mellitus. J Diabetes Res 2017; 2017: 8615769.

34. Dias VM, Pandini JA, Nunes RR, Sperandei SL, Portella ES, Cobas $\mathrm{RA}$, et al. Effect of the carbohydrate counting method on glycemic control in patients with type 1 diabetes. Diabetol Metab Syndr 2010; 2: 54.

35. Golmayo Gaztelu L, Ros Perez P, Alonso Blanco M, MartinFrias M, Barrio Castellanos R. [Nine-year longitudinal study of cardiovascular risk factors in Spanish children and adolescents with type 1 diabetes]. An Pediatr (Barc) 2015; 83: 40-6.

36. Hogel J, Grabert M, Sorgo W, Wudy S, Gaus W, Heinze E. Hemoglobin A1c and body mass index in children and adolescents with IDDM. An observational study from 1976-1995. Exp Clin Endocrinol Diabetes 2000; 108: 76-80.

37. Wiegand S, Raile K, Reinehr T, Hofer S, Nake A, Rabl W, et al. Daily insulin requirement of children and adolescents with type 1 diabetes: effect of age, gender, body mass index and mode of therapy. Eur J Endocrinol 2008; 158: 543-9.

38. Bloch CA, Clemons P, Sperling MA. Puberty decreases insulin sensitivity. J Pediatr 1987; 110: 481-7.

39. Demir F. Tip 1 diyabetli çocuk ve adolesanların etyolojiden prognoza retrospektif değerlendirilmesi (1985-2004): İstanbul Üniversitesi Tıp Fakültesi; 2004

40. Poyrazoğlu Ş, Bundak R, Baş F, Darendeliler F, Günoz H. Tip 1 diyabetli çocuklarda büyüme ve puberte. Çocuk Dergisi 2004: 837.

41. Pereira KC, Pugliese BS, Guimaraes MM, Gama MP. Pubertal development in children diagnosed with diabetes mellitus type 1 before puberty. J Pediatr Adolesc Gynecol 2015; 28: 66-71.

42. Rohrer T, Stierkorb E, Heger S, Karges B, Raile K, Schwab KO, et al. Delayed pubertal onset and development in German children 
and adolescents with type 1 diabetes: cross-sectional analysis of recent data from the DPV diabetes documentation and quality management system. Eur J Endocrinol 2007; 157: 647-53.

43. Alemzadeh R, Palma-Sisto P, Parton E, Totka J, Kirby M. Beneficial effects of flexible insulin therapy in children and adolescents with type 1 diabetes mellitus. Acta Diabetol 2003; 40: 137-42.

44. Effect of intensive diabetes treatment on the development and progression of long-term complications in adolescents with insulindependent diabetes mellitus: Diabetes Control and Complications Trial. Diabetes Control and Complications Trial Research Group. J Pediatr 1994; 125: 177-88.

45. Hypoglycemia in the Diabetes Control and Complications Trial. The Diabetes Control and Complications Trial Research Group. Diabetes 1997; 46: 271-86.
46. Levine BS, Anderson BJ, Butler DA, Antisdel JE, Brackett J, Laffel LM. Predictors of glycemic control and short-term adverse outcomes in youth with type 1 diabetes. J Pediatr 2001; 139: 197203.

47. Rosenbauer J, Dost A, Karges B, Hungele A, Stahl A, Bachle C, et al. Improved metabolic control in children and adolescents with type 1 diabetes: a trend analysis using prospective multicenter data from Germany and Austria. Diabetes Care 2012; 35: 80-6.

48. Guy J, Ogden L, Wadwa RP, Hamman RF, Mayer-Davis EJ, Liese $A D$, et al. Lipid and lipoprotein profiles in youth with and without type 1 diabetes: the SEARCH for Diabetes in Youth case-control study. Diabetes Care 2009; 32: 416-20. 